\title{
Studies in the Cytology of Pteridophyt:
}

\section{On the Nature of the "Border-brim"."1)}

\author{
By
}

\section{Akira Yuasa.}

Received September 5, 1935.

In Pteridophyta the spermatogenesis has been studied by BELAJEFF (1898) in Gymnogramme and Equisetum, by ArNoldi (1910) in Salvinia, by Shaw (1898) in Onoclea and Marsilia, by Campbell (1907) in Ophioglossum, by Yamanouchi (1908) in Nephrodium, by Sirarp $(1912,1914)$ in Equisetum and Marsilia and by Allen (1914) in Adiantum and Aspidium. According to them a spherical blepharoplast appears in the spermatid at first (laying aside the question of the homology of centrosome and blepharoplast), elongates along the surface of the nucleus and at last coalesces with the nucleus, bearing many cilia.

In various plants it has been recognized by many authors that the blepharoplast originates from the centrosome. In Pteridophyta the homology of the blepharoplast and the centrosome has been asserted by BELAJEFF (1898) in Gymnogramme sulphurea and Equisetum arvense and by SHARP (1912, 1914) in Equisetum arvense and Marsilia quadrifolia, but the origin of the centrosome has not been made clear. Ineno, however, has stated in 1903 that in the spermatogenesis of Marchantia polymorpha the centrosome comes out of the nucleus of the spermatogenous cell. On the other hand, in Oedogonium, Vaucheria and Cladophora (Strasburger 1892), Chara (BelaJefF 1894, MotTier 1894) and Isoetes (Sinibata 1902) the blepharoplast has been thought to differenciate from the cytoplasm of the spermatid, while in Dioon (Cinamberlain 1909), Derbesia (Davis 1908), Polytrichum (J. \& W. van Leewen-Reijnvaan 1907), Mnium (J. \& W. van LeewenReijnvane, Anthroceros (Baghee 1924), Mnium (Wilson 1911) and Atrichum (WILson 1911) it has been supposed to originate from the nucleolus (according to the classification of YAzawa 1931).

As mentioned above, in Eufilicineae, Marsiliaceae and Equisetaceae the blepharoplast was thought to have a centrosomal origin, while in Isoetes a

1) Read before the Botanical Society of Japan, February 9, 1935. 
cytoplasmic. In Salviniaceae, Ophioglossales, Lycopodiales and Psilotales the origin of the blepharoplast has not yet been clarified.

The writer (1932,1933a, 1933b, 1933c, 1934,1935), however, has observed that in Pteridophyta the true cilia-bearing portion is not the so-called blepharoplast which has long been thought to be the cilia-bearer, but the "cilia-bearing band" (Figs. 1, 2, 4, cb) ["cilia-bearing portion", (Fig. 3, $c b p)$ in the case of Isoetes japonica AL. BR.]. The same structure of the spermatozoid has been also shown by Roger's (1926/27), MÜ̈mborf (1930), and Dracinscm $(1930,1931)$. The completed blepharoplast which was thought to be the cilia-bearing portion by various authors has been designated as the "border-brim" (Figs. 1, 2, 3, 4, b) by the writer (1932). According to the writer's oponion (1934) all of the "border-brim", "ciliabearing band" and "lateral bar" (Fig. 1, $l$ ) develop from the spherical blepharoplast of the early stage and they must be generally designated
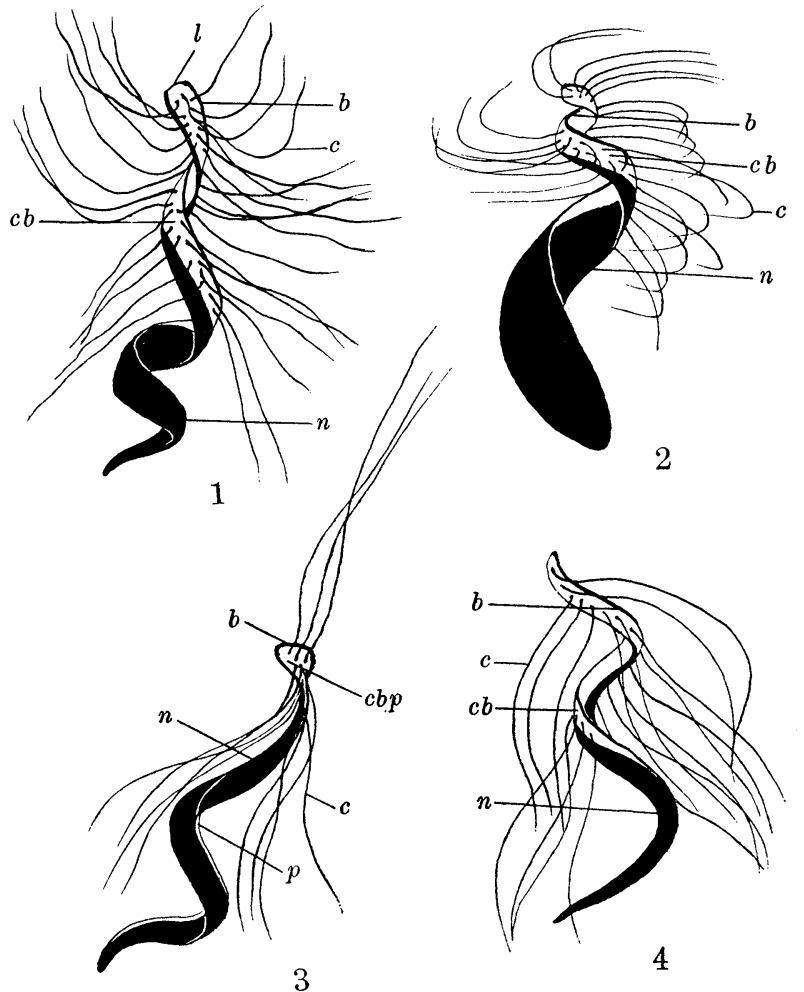

Figs. 1-4. The spermatozoids of Pteridophyta, somewhat schematically drawn.

Fig. 1. A species of Eufilicineae. Fig. 2. Equisetum arvense L. Fig. 3. Isoetes japonica AL. BR. Fig. 4. Salvinia natans HoFrM. $b$, border-brim; $c$, cilium; $c b$, cilia-bearing band; $c b p$, cilia-bearing portion; $n$, nucleus; $l$, lateral bar; $p$, cytoplasmic band. 
as the blepharoplast. The blepharoplast means the body which develops the cilia, but usually the completed cilia-bearer is also included in this term.

To make clear the origin of the blepharoplast, it is one of the important and necessary ways to know the nature of the blepharoplast (including "border-brim", "lateral bar" and "cilia-bearing band"). In the present paper the nature of the blepharoplast (especially the "border-brim") has been studid in th spermatozoids of Mattenccia orientalis Trevir, Adiantum capillus-veneris L., Pteris cretica L. var. albo-lineata Hк. and Isoetes japonica AL. BR.. The dried preparations were stained with various nucleus- or cytoplasm-staining dyes and tested by the microchemical method. In making the dried preparations the hanging drop containing spermatozoids were evaporated on the slide either without fixing or after fixing with absolute alcohol or over osmic fumes (for a few minutes).

\section{In the cases of Matteuccia orientalis Trevir, Adiantum capillus-veneris $\mathrm{L}$. and Pteris cretica $\mathrm{L}$. var. albo-lineata Hк.}

When stained with the nucleus-staining dyes both the nucleus and the "border-brim" of the spermatozoid show almost the same staining reaction. They swell in a certain extent by the action of acetic acid. The result of staining with the nucleus-staining dyes are shown as follows $(++++$, deeply stained; +++ , somewhat deeply stained; ++ , lightly stained; + , very lightly stained; - , unstained):

\begin{tabular}{|c|c|c|c|c|}
\hline Cytoplasm-staining dyes. & Nucleus. & $\begin{array}{l}\text { Border- } \\
\text { brim. }\end{array}$ & $\begin{array}{c}\text { Cilia-bearing } \\
\text { band. }\end{array}$ & Cilia. \\
\hline Haematoxylin & ++++ & +++ & + or - & + or - \\
\hline Aqueous solution of gentian violet & ++++ & $+t+$ & + or - & +or - \\
\hline Carm-alum & $+++t$ & $+t+$ & - & - \\
\hline Safranin solved in aniline water & $+t+t$ & $+t+t$ & ++ & ++ \\
\hline Alcoholie $(95 \%)$ solution of safranin & $+++t$ & $++t$ & ++ & ++ \\
\hline Anthracenblue (chrom-alum) & $+++t$ & $++t$ & - & - \\
\hline Alizarincyanin (chront-alum) & ++++ & $+t+t$ & - & - \\
\hline Alizarinblue (chrom-alum) & $++t+$ & +++ & - & - \\
\hline Aceto-carmine & $++t+$ & $+t+$ & ++ & ++ \\
\hline Methylgreen solved in $45 \%$ acetic acid & +++ & +++ & ++ & ++ \\
\hline $\begin{array}{l}\text { Double staining with safranin and light } \\
\text { green }\end{array}$ & red & red & blue & blue \\
\hline FLEMMING triple staining & red & red & light yellow & light yellow \\
\hline EHRLICH triacid staining & blue & blue & light red & light red \\
\hline
\end{tabular}


With the cytoplasm-staining dyes both the nucleus and the "borderbrim" as well as the "cilia-bearing band" and cilia are stained almost homogeneously.

\begin{tabular}{|l|c|c|c|c|}
\hline \multicolumn{1}{|c|}{ Cytoplasm-staining dyes. } & Nucleus. & $\begin{array}{c}\text { Border- } \\
\text { brim. }\end{array}$ & $\begin{array}{c}\text { Cilia-bearing } \\
\text { band. }\end{array}$ & Cilia. \\
\hline Aqueous solution of fuchsin (acid) & +++ & +++ & ++ & ++ \\
Alcoholic solution of light green & ++ & ++ & ++ & + \\
Aqueous solution of orange G. & ++ & ++ & ++ & ++ \\
Eosin & + & + & + & + \\
Aequeous solution of aniline blue & +++ & +++ & ++ & ++ \\
\hline
\end{tabular}

Judging from the results of the above mentioned staining reactions the "border-brim" seems to have some resemblance in its nature to the nucleus of the spermatozoid, but the former is negative to FEULGEN's nucleal-staining reaction, while the latter is positive. Both the nucleus and the "border-brim" stain lightly red when stained with Sudan III ( $0.1 \mathrm{gr}$. Sudan III solved in 20 ec. of $95 \%$ alcohol). They stain black red, showing the containing of lipoids, while the cilia and the "cilia-bearing band" almost remain unstained when treated with Sudan III and haematoxylin. BUILET's and xanthoproteic reactions were proved to be negative to both nucleus and "border-brim," while the MiLLon's reaction was positive. From these reactions both the nucleus and the "border-brim" are thought to contain lipoids and proteins.

There is, however, a question whether the "border-brim" is homologous with any one of the starch-grain, plastid or chondriome. The starchgrain, however, is envloped by the plastid-hull and exists in this state in the cytoplasm of the spermatid throughout the course of spermatoteleosis. So the homology between the "border-brim" and the starch grain or plastid must be denied. The "border-brim" does not solve in an alkaline solution and is not stained in vital with a solution of janus green. So the "border-brim" is thought not to be homologous with the chondriome. In fact, EMberger (1922) traced the chondriome during the course of spermatogenesis in Adiantum capillus-veneris L., showing no relation with the "border-brim".

The cilia and the "cilia-bearing band" are cytoplasmic, though they show some differences in their staining reactions. As stated in the previous paper (1934) these two portions develop secondarily from the blepharoplast.

The test was also made to the "border-brim" in the spermatozoid of Isoetes japonica $\mathrm{AL}_{\mathrm{L}}$ BR., which was thought to have a cytoplasmic origin. 
In the case of Isoetes japonica AL. BR.

The staining reactions are as follows:

\begin{tabular}{|l|c|c|c|c|c|}
\hline \multicolumn{1}{|c|}{ Nucleus-staining dyes. } & Nucleus. & $\begin{array}{c}\text { Border- } \\
\text { brim. }\end{array}$ & $\begin{array}{c}\text { Cilia- } \\
\text { bearing } \\
\text { portion. }\end{array}$ & $\begin{array}{c}\text { Cyto- } \\
\text { plasmic } \\
\text { band. }\end{array}$ & Cilia. \\
\hline Haematoxylin & ++++ & ++++ & + or & + or - & + or - \\
Aqueous solution of gentian violet & ++++ & ++++ & + or & + or - & + \\
Safranin in aniline water & ++++ & +++ & ++ & ++ & ++ \\
Aqueous solution of safranin & ++++ & +++ & ++ & ++ & ++ \\
Alcoholic (95\%) solution of safranin & ++++ & +++ & ++ & ++ & ++ \\
Anthracenblue (chrom-alum) & +++ & ++ & - & - & - \\
Alizarincyanin (chrom-alum) & +++ & ++ & - & - & - \\
Alizarinblue (chrom-alum) & +++ & ++ & + or - & + or - & + or - \\
Aceto-carmine & ++++ & +++ & ++ & ++ & ++ \\
Methylgreen solved in $45 \%$ acetic \\
acid
\end{tabular}

\begin{tabular}{|c|c|c|c|c|c|}
\hline Cytoplasm-staining dyes. & Nucleus. & $\begin{array}{l}\text { Border- } \\
\text { brim. }\end{array}$ & $\begin{array}{c}\text { Cilia- } \\
\text { bearing } \\
\text { portion. }\end{array}$ & $\begin{array}{c}\text { Cyto- } \\
\text { plasmic } \\
\text { band. }\end{array}$ & Cilia. \\
\hline Aqueous solution of fuchsin & - & +++ & - & +++ & + \\
\hline $\begin{array}{l}\text { Aqueous solution of fuchsin } \\
\text { with drops of } 45 \% \text { acetic acid }\end{array}$ & ++ & $++t$ & - & +++ & ++ \\
\hline Eosin & +++ & +++ & ++ & ++ & ++ \\
\hline Aqueous solution of orange $G$. & ++ & ++ & ++ & +++ & ++ \\
\hline Aqueous solution of aniline blue & - & +++ & - & $+t+$ & + \\
\hline $\begin{array}{l}\text { Alcoholic }(75 \%) \text { solution of light } \\
\text { green }\end{array}$ & ++ & ++ & ++ & ++ & ++ \\
\hline
\end{tabular}

\begin{tabular}{|c|c|c|c|c|c|}
\hline Feulgen's nucleal-staining & Nucleus. & $\begin{array}{c}\text { Border- } \\
\text { brim. }\end{array}$ & $\begin{array}{c}\text { Cilia- } \\
\text { bearing } \\
\text { portion. }\end{array}$ & $\begin{array}{c}\text { Cyto- } \\
\text { plasmic } \\
\text { band. }\end{array}$ & Cilia. \\
\hline & + & - & - & - & - \\
\hline
\end{tabular}

Judging from the staining reactions, the "border-brim" in the spermatozoid of Isoetes japonica AL. Br. resembles in its nature the nucleus though they also show some resemblance to the cytoplasm. Stained with Sudan III the "border-brim" shows the reaction of lipoids. BUIRET's, 
xanthoproteic and MiLlon's reactions are negative in the case of the "border-brim".

When the spermatozoid is dried up, the cilia are destructed, and the nucleus is deformed, while the "border-brim" remains without change. With $40 \% \mathrm{NaOH}$ most of the spermatozoid-body is destructed, while the "border-brim" remains as before. The spermatozoid-body shows no change with $33 \% \mathrm{HNO}_{3}$, but it solves completely when boiled with the latter. The "border-brim" is fixed and swells in some extent with $45 \%$ acetic acid. It is also fixed with alcohol, iodine solution, potassium iodide iodine solution, formalin $(2 \%)$, osmic acid or potassium bichromate solution. When stained with Altmann's method the nucleus and the "border-brim" are black red, while the cilia, "cilia-bearing portion" and the "cytoplasmic band" are red. From these results the "border-brim" seems to have some resemblance in its nature to the chondriome, but it is not stained in vital with a solution of janus green.

During the spermatogenesis of Isoetes japonica AL. BR. only the nucleus is positive to FEuLgen's nucleal reaction and the "border-brim" is quite negative to this reaction (Figs. 5-12).
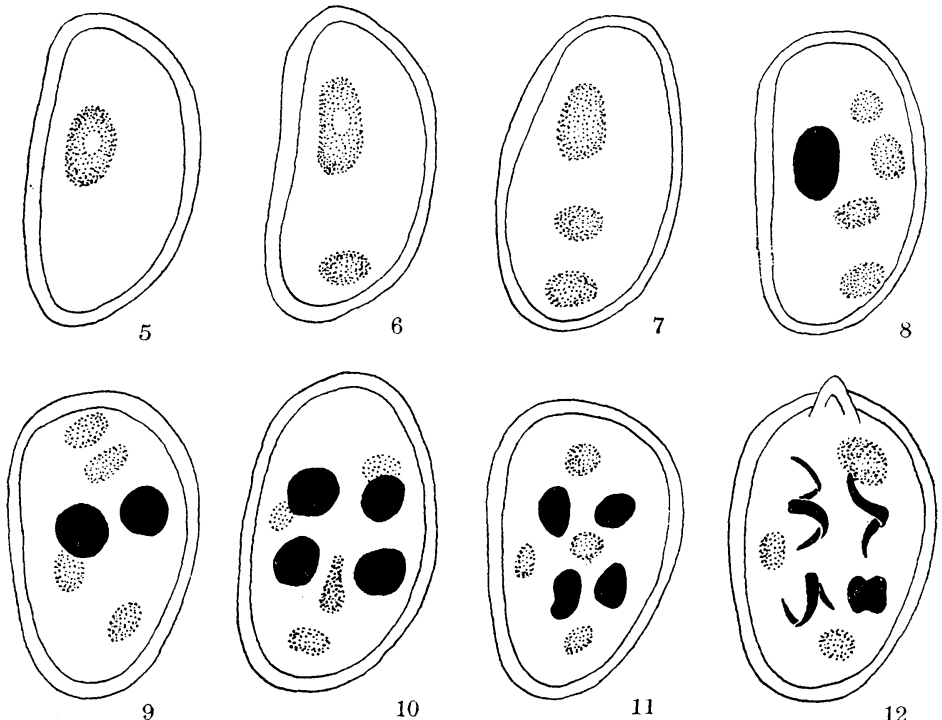

Figs. 5-12. Spermatogenesis in Isoetes japonica AL. BR. studied by the FEULaEn's nucleal-staining method. Only the nucleus is positive. The nuelei of spermatogeous cells and spermatids are shown to be black and those of other cells stippled.

From the results mentioned above it is to be concluded that the "border-brim" shows some resemblance in its nature to the nucleus, but 
contains no thymusnucleic acid in the spermatozoids of Mattenccia orientalis Trevin, Adiantum capillus-veneris L. and Pteris cretica L. var. albo-lineata $\mathrm{IK}_{\mathrm{K}}$ (perhaps all the species of Eufilicineae). It may have some relation with the nucleus in its origin, but no direct relation with the chromatin. The "silia-hearing band" and the "lateral bar" differenciate secondarily from the blebharoplast in the early stage. The cilia devalop on one side of the surface of the "cilia-bearing band". In the spermatozoid of Isoetes japonica $\Lambda_{\mathrm{L}}$. BR. the "border-brim" shows the nuclear nature though it does not contain thymusnucleic acid, but on the other hand it is thought to have some resemblance to the cytoplasm.

In both cases the "border-brim" has the rigidity in its nature.

The writer wishes to express his sincere thanks to the director Dr. II. IIATTon and Dr. Y. Sinoto, who read through the manuscript and gave (riticisms.

The expences for carrying out this study were partly defrayed out of a grant from the "Nippon-Gakuzyutu-Sinkôkwai" (The Foundation for the Promotion of Science and Industrial Research of Japan) to which the writer wishes to express his best thanks.

The Tokugawa Institute for Biological Research, Mejiro-Mati, Tokyo.

\section{Literature.}

AllikN, R. F. 1914. Studies in spermatogenesis and apogamy in ferns. Trans. Wis. A(::ad. S(.i. Arts and Letters, $17: 1-5) 6$.

AkNornd, (x. 1910. Beiträge zur Morphologie der Keimung von Salvinia natans. Flora, 100 : 121-139.

BELAJjFr, W. 1894. Über Bau und Entwicklung der Spermatozoiden der Pflanzen. i1)., $79: 1-48$.

1898. Über die Cilienbildner in den spermatogenen Zellen. Ber. d. Deut. bot. Gesells., 16: 140-144.

1899. Ü̉ die Centrosome in den spermatogenen Zellen. ib., 17: 199-20.).

(Anpbisl, D. H. 1907. Studies on the Ophioglossaceae. Ann. d. Jard. Bot. d. Buitenzorg, 21 : 138-194.

Dracinschi, M. 1930. Über das reife Spermien der Filicales und Pilularia globulifera I. Ber. d. Deut. bot. Gesells., 48: 295--311.

1931. Über das reife Spermium von Equisctum. Bull. Fac. St. Cëmauti, 5: $84-95$.

EMberger, L. 1922. L'évolution des plastes dans le règne végétale. Rer. Sci., 60: 46. Feulgen, R. and Rossenbeck, H. 1924. Mikroskopisch-chemischer Nachweis einer Nueleinsäure vom Typus der Thymusnucleinsäure und die darauf beruhende clektive Färbung von Zellkernen in mikroskopischen Präparaten. Hoppe-SEILER's Zeits. f. physiol. Chemie, 135 : 203-248.

Hanstein-Cranner, B. 1919. Beiträge zur Biochemie und Physiologie der Zellwand 
und der plasmatisehen Grenzsehichten. Ber. d. Deut. bot. Gesells., 37: 38(1-391. IKENo, S. 1903. Die Spermatogenese von Marchantia polymorpha. Beih. lot. Zentralb]., 15: $65-88$.

Münlnorf, A. 1930. Berichtungen und Ergänzungen unserer Konntnisse äber die Morphologie und Histologie pflanzlieher Spermien. Biol. Gen., 6: 4.77-482.

Ň̌nEc, B. 1920. Zur Mikrochemie der Chromosomen. Ber. d. Deut. hot. (iesells., 27: $43-47$.

Pratsk, A. 1920. Die Chemie des Zellkernes. Biol. Zentrallh., 40: s\&-11:2.

RogERs, L. M. 1926/27. Development of the archegone and studies in fertilization in Lygodium palmatum. La Cellule, $37: 325-352$.

Sharp, I. W. 1912. Spermatogenesis in Equisetum. Bot (Yaz., 54: s!9-119.

1914. Spermatogenesis in Marsilia. il., 58: 420-431.

Snaw, W. R. 1898. Über die Blepharoplasten hei Onoclea und Marsilia. Ber. 1. Deut. bot. Gesells., 16: 177-184.

SHватА, K. 1902. On the development of spermatozoids and fertitization in Isoctes japonica A r. Br. (Nipponese). Bot. Mag. (Tokyo), 16: 139-140.

Shonke, N. and Shigenaga, M. 1933. ('hemical study of plant unelei in rest and mitosis. Cytologia, 4: 189-221.

Wilson, M. 1911. Spermatogenesis in the Bryophyta. Ann. of Bot., 25: 41.5-4.57.

Yanaha, (x. 1932. Üher die Färlbarkeit der fixierten Zellstrukturen. Se.i. Rep. Tôkyô Bumrika-I)aigaku, See. B., Vol. 1, No. 1: 1-21.

Yamanobent, S. 1908. Spermatogenesis, oogenesis and fertilization in Nephrorlium molle. Bot. (xaz., 45: 14.5-175.

YAZAWA, H. 1931. On the spermatogenesis in Malinoa rrispata. (ST.) MHYAKE. (Yytologia, 2: 157-173.

YUAss, A. 1932. Studies in the Cytology of Pteridophyta. 1. On the spermatozoid of Pteris cretica I. var. albo-lineata IJk. Bot. (aiz. (Tokyo), 46: $+-1=$.

1933a. Ditto. II. The morphology of spermatozoids of some ferns. (ytologia, 3: 30 - -337 .

1933h. Ditto. III. The morphology of spermatomoids in oight sperese of ferms. Bot. Malg. (Tokyo), 47 : $681-6966$.

1933r. Ditto. IV. On the spermatozoids of Seleginella, Isoetes ant stalvinia. il., 47 : 697-709.

1934. Ditto. V. Spermatoteleosis in Notogramme japonica l'ress and Pteris multifula Ponder" with special reference to the development of horder-brim, lateral bar and cilia-baring band. Jour. Fate. Sci. Tmp. Tnir. Tokyo, Sere. III, Bot., Vol. 4, Pt. $4: 389-397$.

193.). IDitto. VIII. The morphology of spermatozoids in seren speries of ferns. Bot. Mag. ('Tokyo), 49: 375-382. 